\title{
ВЕРБАЛЬНА АГРЕСІЯ: МІЖ НАСИЛЬСТВОМ І БЕЗСИЛЛЯМ
}

Оксана Гаврилів

oksana.havryliv@univie.ac.at Віденський університет, Австрія Львівський національний університет імені Івана Франка, Україна

\author{
Received November 4, 2017; Revised November 22, 2017; Accepted December 2, 2017
}

Анотація. У статті здійснено диференціацію понять «вербальна агресія» - «вербальне насильство», які дотепер розглядалися синонімічно не лише філософами мови, а й мовознавцями. Виділено спектр функцій вербальної агресії від комунікативної інтенції «образа, приниження» до жартівливого, лаудативного вживання (фіктивна вербальна агресія). Висунуто гіпотезу про комплексн ість комунікативних інтенцій, які лежать в основі вербальноагресивних актів і вирішальну роль катартичної фун кції. Результати дослідження підтвердили нашу гіпотезу про комплексний характер вербальної агресії, який виявляється в поліфун кц іональності і домінуванні катартичної функції. Емп іричну основу творять усні і письмові опитування мешканців м. Відень (Австрія). Загалом опитано 386 осіб різного віку, соціального стану і в однаковій кількості представників обох статей.

Ключові слова: вербальна агресія, вербальне насильство, мова і суспільство, агресивні мовленнєві акти, пейоративи.

Havryliv, Oksana. Verbal Aggression: Between Violence and Impotence.

Abstract. In this article a clear line between two terms "verbal aggression" vs. "verbal violence" is drawn. Based on the results of survey case studies held by the author "verbal aggression" is viewed as a complex linguistic phenomenon. Both intentions aimed at humiliation of the addressee (then verbal aggression equals to verbal violence), and intentions that are not aimed at verbal violence called "efficient" may lie at the core of the phenomenon. The "productive" functions of verbal aggression, emphasized in the field of psychology, are not sufficiently studied from linguistic perspective. Special attention in the article is given to the relation of verbal and physical aggression. Based on the theory of speech acts and the theory of performativity we view language as an action and distinguish two possibilities of aggressive speech acts: the one that is aimed at violence and the non-violent one. In the former case it is language of violence as a separate and independent form of violence.

Keywords: verbal aggression, language violence, language and society, aggressive speech acts, pejorative words.

\section{1.Вступ}

Останніми роками тема вербальної агресії викликає наукове зацікавлення передусім у сегменті мовного насильства. Безсумнівно, це пов'язане із зростаючою агресивністю загалом і виявами фізичної агресії в різних куточках світу зокрема. Дослідження вербальної агресії сприяє кращому розумінню цього все ще табуйованого феномену, виконує превентивну функцію, спонукаючи через саморефлексію до мовних змін на користь ненасильницької комунікації, а тому є першим кроком на шляху до зниження агресивності. Те саме можемо сказати і про детабуїзацію теми, адже частотність вживання пейоративів перебуває у прямому зв’язку з їх табуйованістю - яскравим прикладом цього є

(C) Гаврилів Оксана (2017). East European Journal of Psycholinguistics, 4(2), 34-46. DOI: 10.5281/zenodo.1148919 
Росія $з$ iї традиційними табу і заборонами на пейоративи і з відповідним багатим та інтенсивним пейоративним словниковим складом й навіть окремим мовним різновидом (мат), який базується виключно на пейоративній лексиці.

Проте темою мовного насильства переважно займається філософія мови (Herrmann u.a., 2007, Krämer, 2010, Liebsch, 2007), а нечисленні мовознавчі праці обмежуються дослідженням узуальних мовних засобів, їхніх морфологічних, структурно-семантичних, синтаксичних особливостей (Aman, 1972, Ermen, 1996, Faust, 1970, Hess-Lüttich, 2008, Holzinger, 1984, Lötscher, 1980, Opelt, 1965, Sornig, 1975), лексикографічного аспекту (Mokienko, Walter, 1999) та - 3 компаративного погляду - міжмовних особливостей вербальної агресії (Burgen, 1998, Gauger, 2012, Жельвіс, 1997). Аспект сприйняття вербальної агресії адресатом, який є вирішальним 3 перспективи мовного насильства, залишається натомість недослідженим: на прагматичному рівні мовознавці переважно не виходять за межі ілокутивних актів і не аналізують пов'язаних 3 ними перлокутивних актів. Дослідження перлокуції уникали й самі засновники теорії мовленнєвих актів (Д. Остін, Д. Серль) - оскільки впливи на адресата вже ближчі до теорії дії та психології. Для того, щоб осягнути феномен вербальної агресії комплексно, в його інтеракційному вимірі, важливу роль належить приділити саме дослідженню сприйняття і реакцій на агресивні мовленнєві акти.

3 огляду на те, що вербальна агресія у мовознавстві залишається мало дослідженою темою, а поняття «вербальна агресія» розглядається як синонім до вербального насильства (Ermen, 1996, Gauger, 2012, Holzinger, 1984, Kiener, 1983, Lötscher, 1980, Opelt, 1965, Rehbock, 1987, Schumann, 1990, Ставицька, 2008), актуальність цієї статті очевидна, адже ми не тільки пропонуємо поліфункціональне бачення феномену вербальної агресії, а й проводимо чітку лінію між вербальною агресією і вербальним насильством, розглядаючи агресивні мовленнєві акти у двох площинах - насильницьких і ненасильницьких інтенцій.

\section{2. Методи дослідження}

Мета дослідження - виокремити спектр функцій вербальної агресії, які є підставою для розмежування понять «вербальна агресія» i «вербальне насильство». Для досягнення цієї мети ми поставили перед собою такі завдання: визначити інтенції, які лежать в основі вживання агресивних мовленнєвих актів і виділити функції вербальної агресії; з огляду на тему статті - описати полярні функції вербальної агресії; поряд із деструктивними, через які передусім визначається вербальна агресія (Biffar, 1994:17, Holzinger, 1984:34, Schumann, 1990:260), виокремити iï продуктивні функції; розмежувавши вербальну агресію і вербальне насильство, окреслити перспективи їхніх подальших досліджень в суспільно-політичному контексті: взаємозв' язки вербальної і фізичної агресії, структурного насильства - 3 вербальним і фізичним насильством.

У праці застосовано такі методи дослідження: квалітативні методи опитування (письмове опитування за допомогою короткого і розгорненого питальника, усне опитування у формі інтенсивного частково стандартизованого інтерв'ю), 
контекстуальний аналіз, прагмалінгвістичний аналіз (дослідження ілокуцій i перлокуцій), конверсаційний аналіз.

\section{3. Процедура дослідження й обговорення результатів}

\section{1. Функції вербальної агресії}

Хоча негативні емоції та їхній вербальний вияв є важливими складовими нашого щоденного життя, з лінгвістичної перспективи проблема взаємозв' язку понять «мова» і «емоція» до останнього часу залишалася «екзотичною темою з дрібкою езотерики» (Schwarz-Friesel, 2013) на маргінесі прикладного прагмафункціонального мовознавства. Дисонанс між важливістю емоцій для людини та станом їх дослідження можемо пояснити негативною концептуалізацією феномену «емоція» загалом, i негативних емоцій зосібна - їм відводять дезорганізаційний та дестабілізаційний вплив на комунікацію (пор. також Fiehler (1990:20) та Schwarz-Friesel (2013:10)). Ця традиція бере початок від картезіанської філософії (cogito ergo sum) з іï виразним розмежуванням духу і тіла, розуму і почуття, що посилилося в епоху Просвітництва. Сьогодні науковці (чи-то в нейронауці, чи в психологіi, психотерапії, психоаналізі, психолінгвістиці) виходять із комплексних взаємовпливів когнітивних та емоційних компонентів. Розглянемо ці взаємовпливи на прикладі агресивних мовленнєвих актів ${ }^{1}$, які можуть вживатися і в стані афекту, і в ситуаціях 3 невисокою емоційною напругою. У першому випадку когнітивний компонент справді відходить на другий план, адже для афекту - стану сильного збудження, що не підлягає контролю і подібний до рефлексу, - характерний неінтенційний несвідомий компонент. Проте в більшості випадків вживання агресивних мовленнєвих актів ми маємо справу 3 когнітивно керованими емоційними станами і, відповідно, - 3 контрольованими емоціями. Співвідношення між емоційністю і когнітивністю найкраще ілюструють випадки непрямої вербальної агресії. Процентне співвідношення між прямою та непрямою формами вербальної агресії демонструють Табл. 1 та Табл. $2^{2}$.

Таблицฺя 1

\section{Форми вербальної агресії}

(на основі опитувань, проведених 2006-2007 року)

\begin{tabular}{|c|c|}
\hline Пряма вербальна агресія & Непряма вербальна агресія \\
\hline $34 \%$ & $66 \%$ \\
\hline
\end{tabular}

\footnotetext{
${ }^{1}$ Спираючись на класифікацію Серля (Searle 1971:221), який виокремлює «експресивні мовленнєві акти», за допомогою яких мовець виявляє свої почуття і ставлення, виокремлюємо в цій групі «агресивні мовленнєві акти», за допомогою яких мовець звільняється від негативних емоцій. До агресивних мовленнєвих актів належать: «лайка», «прокльон -вигук», «прокльон-побажання», «погроза», «брутальний наказ» (Havryliv 2009:22).

${ }^{2}$ Кожне $з$ опитувань проводилося усно у формі частково стандартизованого інтерв 'ю із 36 особами віком від 18 до 85 років у трьох соціальних групах (по 12 осіб в кожній групі пропорційно 6 жінок та 6 чоловіків): група 1 - особи із неповною шкільною освітою (Matura), група 2 - особи із повною шкільною освітою, група 3 особи 3 вищою освітою.Опитаних осіб просили представити дві форми вербальної агресії у їхньому особистому вжитку таким чином, щоб у сумі вийшло $100 \%$.
} 
Таблиия 2

\section{Форми вербальної агресії}

(на основі опитувань, проведених 2013-2016 року)

\begin{tabular}{|c|c|}
\hline Пряма вербальна агресія & Непряма вербальна агресія \\
\hline $32 \%$ & $68 \%$ \\
\hline
\end{tabular}

До непрямої відносимо вербальну агресію, яка відбувається за відсутності адресата (монологічно або в присутності третьої особи - слухача). До цієї форми належить також агресія подумки. Непряма агресія скерована і до осіб, до яких спонтанно важко звернутися безпосередньо (політики, спортсмени, актори, журналісти), і до тих, на чию адресу пряма вербальна агресія може мати негативні наслідки: клієнти, ділові партнери, керівництво, невідомі особи в громадських місцях, чиїх несподіваних реакцій - в тому числі й фізичної агресії - ми побоюємося. Виховання також є тим чинником, який переводить агресію в громадських місцях з прямої в непряму форму. У (напів)свідомому виборі непрямої форми вербальної агресії виявляється перевага когнітивного компоненту.

Дотепер немає консенсусу щодо дефініщії агресії та насильства; вчені одностайні лише щодо руйнівного компоненту, що й пояснює те, чому поняття «вербальна агресія» $\mathrm{i}$ «вербальне насильство» вживаються сино німічно. Такий підхід - визначення вербальної агресії через інтенцію образи, приниження, перемоги над адресатом - зустрічаємо і в мовознавчих працях (Ermen, 1996, Gauger, 2012, Holzinger, 1984, Kiener, 1983, Lötscher, 1980, Opelt, 1965, Rehbock, 1987, Schumann, 1990, Ставицька, 2008): «Мета вербальної агресії - перемога над супротивником» (Biffar, 1994:17); «/.../лайка служить мовцеві вербальним засобом образи, приниження адресата, демонстрації своєї вищості» (Holzinger, 1984:34); «/.../лайка реалізовує намір мовця, спрямований на образу адресата» (Schumann, 1990:260).

На противагу до наведених дефініцій, результати наших досліджень показують, що вербальна агресія - комплексний феномен, в основі якого можуть лежати різні інтенції, а намір образити відіграє несуттєву роль (11\% в обидвох опитуваннях - див. Таблиця 3 та Таблиця 4) ${ }^{1}$. Таким чином, підтверджується наша гіпотеза про те, що вербальна агресія скерована передусім на звільнення від негативних емоцій, а не на образу адресата. Опитування українців демонструють подібні результати: за даними соціологічного опитування компаніï Research\&Branding Group), причинами вживання лайливих слів українці називають підвищення емоційності мовлення (48 \%), необхідність зняття психологічної напруги (45 \%) і больовий шок (28\%). У двох останніх випадках лайка виконує катартичну функцію.

\footnotetext{
136 усно опитаних осіб попросили предс тавити функції, які для них виконує вербальна агресія, таким чином, щоб у сумі вийшло $100 \%$.
} 
Функції вербальної агресії

Таблиия 3

(на основі опитувань, проведених 2006-2007)

\begin{tabular}{|c|c|c|}
\hline $\begin{array}{c}\text { Звільнення від } \\
\text { негативних емоцій }\end{array}$ & Образа & $\begin{array}{c}\text { Жартівливе } \\
\text { вживання (в колі } \\
\text { друзів, до дітей та ін.) }\end{array}$ \\
\hline $64 \%$ & $11 \%$ & $25 \%$ \\
\hline
\end{tabular}

Таблиия 4

Функції вербальної агресії

(на основі опитувань, проведених 2013-2016)

\begin{tabular}{|c|c|c|}
\hline $\begin{array}{c}\text { Звільнення від } \\
\text { негативних емоцій }\end{array}$ & Образа & $\begin{array}{c}\text { Жартівливе } \\
\text { вживання (в колі } \\
\text { друзів, до дітей та ін.) }\end{array}$ \\
\hline $73 \%$ & $11 \%$ & $16 \%$ \\
\hline
\end{tabular}

При жартівливому, пестливому, лаудативному вживанні пейоративів (у колі друзів, знайомих і колег, до дітей, у спілкуванні закоханих) маємо справу 3 фіктивною вербальною агресією: локуція і пропозиція збігаються із справжньою вербальною агресією, чого не можемо сказати про ілокуцію і перлокуцію. Така невідповідність між формою (сказане) і змістом (задумане) зумовлюється домінуванням прагматичної функції над функцією повідомлення. У фіктивній вербальній агресії актуалізується амбівалентний принцип пейоративів, який Егальт вважає «підмурівком гумору» (Ehalt, 2015:8).

3 огляду на сформульовану назву статті, розглянемо полярні функції вербальної агресії:

1. Вербальна агресія як заміна і як провокація до фізичної агресії;

a) Одна 3 найважливіших функцій вербальної агресії полягає в заміні фізичної (за даними Кінера (Kiener, 1983:295) вербальна агресія значно домінує над фізичною, становлячи 93 \% загальної агресивної поведінки). Найкраще цей взаємозв'язок бачимо на прикладі мовленнєвого акту «погроза», адже він вербалізує ті фізичні дії, яких мовець завдав би адресатові, якби не боявся його, судових позовів чи інших санкцій. Функцію заміни виконує і популярне антипутінське гасло Путін хуйло: згадаймо його вживання тодішнім міністром закордонних справ Андрієм Дещицею разом із протестувальниками перед посольством Росії (14-06-2014), що дозволило уникнути штурму посольства i повязаних з цим непередбачуваних наслідків.

б) Рідше і переважно в учнівських і молодіжних колах вербальна агресія може використовуватися як провокація до фізичної.

Функції виконує не лише сама вербальна агресія, а й іï заборона: так заборона Путіним від 1.07.2014 року вживання лайливих слів у 3МI, фільмах, театральних виставах і шоу, творах літератури відкриває на тлі російської агресивної політики нові аспекти взаємозв'язку фізичної та вербальної агресії: 
а) беручи до уваги той факт, що головна функція вербальної агресії полягає у заміні фізичної, із забороною пейоративів відкривається прямий шлях до фізичної агресії;

б) і раніше фільми із вживанням пейоративів в Росії маркували позначками «від 16 років» або «від 18 років», тобто прирівнювали до фільмів з брутальними сценами фізичного насильства, а вербальну агресію, відповідно, - до фізичної. Проте актуальна заборона ставить вербальну агресію вище, відвертаючи тим самим увагу від фізичної агресії та нівелюючи іiі.

2. Вербальна агресія як образа адресата і як вияв міцних дружніх стосунків (пестливе, лаудативне, втішальне вживання пейоративів, корпоративна функція). Таке вживання пейоративів сигналізує «Наша дружба настільки сильна, що їй не зашкодить гра із забороненими словами» (пор.: «культура дражніння i глузування $\epsilon$ індексом тісних стосунків» (Kotthoff u.a., 2012:74)). Передумовою для вдалої фіктивної агресії (коли ілокуція і перлокуція збігаються й адресат не сприймає адресовані до нього агресивні мовленнєві акти образливо) $\epsilon$ фіктивність висловлювання, яка можлива завдяки взаємним знанням про системи цінностей, життєвий досвід, табуйовані теми, слабкі місця і реакції комунікантів. У випадку фіктивних агресивних мовленнєвих актів маємо справу 3 продуктивними функціями вербальної агресії.

3. Вербальна агресія як вияв насильства і безсилля:

a) як вияв влади - усвідомлене інтенційне вживання пейоративів 3 метою демонстрації особливої соціальної позиції, що дозволяє ламати табу на вживання пейоративів) (пор. Ставицька (2008:52) про те, що саме тому мат або його евфемізми полюбляють можновладці. Віктор Єрофєєв у «Російському апокаліпсисі» також наголошує, що мат «... процвітає у владних структурах. Путін користується матом. Як для Сталіна, Хрущова, Брежнєва і Єльцина, мат для нього є авторитарною мовою, мовою влади»; б) вербальна агресія як вияв безсилля, втрати контролю над собою (у стані афекту, з розпачу, коли інші методи, як от конструктивна розмова чи прохання, безрезультатні).

4. Вербальна агресія як напад і як самооборона: агресивні висловлювання можуть вживатися для відлякування супротивника. Так, деякі опитувані стверджують, що вдаються до вербальної агресії у тих випадках, коли побоюються агресивності з боку адресата і діють таким чином на випередження («Іноді я вдаюся до лайки з метою самозахисту, щоб відлякати супротивника і він не захотів зі мною зчіпатися»). Така тактика доречна, якщо про адресата відомо, що він не піде на вербальну чи фізичну конфронтацію, проте вона може бути ризикованою, якщо мовцеві невідомі особливості поведінки адресата, адже вербальна агресія може спровокувати не тільки вербальну агресію у відповідь, але й фізичну. Д. Херубим говорить у другому випадку про «пускову функцію мови для вищих ступенів агресіì (Cherubim, 2013:15): 3 цісю метою не обов'язково вдаватися до агресивних мовленнєвих актів, для агресивно налаштованої особи досить запитати іншого про час, дорогу або попросити цигарку, щоб потрактувати цю відповідь як агресивну і вдатися до фізичного нападу.

5. Функцію протесту, подолання страху і знецінення реальності пояснимо на прикладі вже згадуваного антипутінського гасла Путін хуйло: на час появи 
цього гасла - а це місяць після окупації Криму - негативні емоції громадян України досягли такого рівня, коли катартичної функції лайки було недостатньо. Тому підключився додатковий механізм звільнення - через висміювання - який підсилив катартичну функцію вербальної агресії (оскільки і для лайки, і для сміху важливу роль відіграє функція звільнення - пор. Зигмунд Фройд про роль гумору у подоланні життєвих труднощів (Freud, 1994) або Анрі Бергсон про сміх як «анестезію серця» (цит. за: Kotthoff, 2013:234), що дозволяє короткочасно звільнитися від страждань, страху, болю і смутку). За карнавалістичною теорією Бахтіна, через облаювання i висміювання ми перетворюємо загрозливе i ненависне на комічне, одночасно звільняючись від страху і люті.

Як бачимо, вживання агресивних мовленнєвих актів виконує широкий спектр функцій (В. І. Жельвіс вдається до, на нашу думку, надмірної диференціації, і виділяє 26 функцій (Жельвіс, 1997:99-118), багато з яких ми можемо вважати продуктивними ${ }^{1}$, оскільки до людської комунікації належить i вияв незадоволення, негативних емоцій (емотивна функція мови), референція на незадовільний стан речей чи поведінку адресата, i, відповідно, можливість змінити ïх - функції вербальної агресії, яким у мовознавстві дотепер присвячувалося мало уваги. Зате у психологіі, психіатрії, психоаналізі та гештальттерапії ще з 60-их років минулого століття (вербальна) агресія трактується як продуктивний феномен: так Ж. Бах і Г. Гольдберг розуміють агресію в широкому значенні як «кожну поведінку, яка відрізняється від пасивності» (Bach, Goldberg, 1981:14) i говорять про «продуктивну агресію» (там само:20).

\section{2. Від страху і пасивності до агресії і насильства}

- Гей, ти, бронзове опудало! Хто ти такий $і$ що тут робиш? Чого витрішився на мене? Я тебе не боюся! (Лагерлеф1991:94)

На зв’язок агресивності зі страхом і пасивністю вказують як психологи, так і культурологи, історики, мовознавці: Ж. Бах і Г. Гольдберг (Bach, Goldberg, 1981:185) вважають пасивність і бездіяльність виявом прихованої агресивності, а Стефан Ессель - 93-річний французький колишній дипломат і учасник руху опору, автор знаного в світі есею «Обурюйтеся!» ${ }^{2}$ бачить причину фашизму у «жахливому страху перед більшовицькою революцією». Його гіпотезу поділяє й російська історик, професор московського університету Слєна Галкіна: на запитання «Чому Путін вдався до агресії щодо України?» в інтерв'ю газеті «Високий замок» (Галкіна, 2014:6) вона стверджує, що головною мотивацією було не відродження російської імперії, а проекція на себе української ситуації (Майдан, втеча Януковича), страх за свою владу, а звідси - бажання показати, що революція не приводить до нічого доброго. Галкіна також характеризує росіян як агресивно-пасивних: «Важко сказати, наскільки масштабними мають бути втрати, щоб агресивно-пасивне населення Росї (виділення наше - О. Г.) прокинулося й обернуло свій гнів не проти Америки й України, а проти головного винуватця своїх бід» (Галкіна, 2014:6).

\footnotetext{
1 Продуктивний аспект агресивності закладений в слові етимологічно: лат. «aggressio» від «gressio» (крокувати, крок), що означає як вороже так і нейтральне наближення (http://www.wissen.de/wortherkunft/aggression). 2 вийшов у світ в жовтні 2010 року і вже до лютого 2011 року було продано 1 мільйон екземплярів.
} 
На зв’язок пасивності i (вербальної) агресивності вказують також мовознавці: так, В. Дєвкін вбачає живучість і частотність мовного різновиду «мат» у суспільно-політичній пасивності його носіїв: «Росіянам ніколи не щастило із державною владою. Наділені Богом безмежним терпінням, вони вміли все зносити і віками нести свій хрест (гніт жорстоких безмозких самодержців і їхніх режимів)». Зате в малому вони бунтують проти встановлених правил, порядків, заборон, традицій» (Devkin, 1996:9-10). Заради створення ілюзії бунту (саме в «малому»), свободи, «протистояння будь-якому авторитетові і забороні» (там само:6) в Росії традиційно сильно табуюється вербальна агресія. Функцію сублімації мат не виконує в українській мові, оскільки українці, як показують події останніх десятиріч, вдаються до активних протестів. Вживання матизмів носіями української мови $є$ передусім звичкою (неінтенційне, експлетивне вживання), хоча матірні слова можуть вживати 3 певною метою (підсилення експресивності, категоричності сказаного, демонстрація «близькості до народу»). Наслідком тривалого вияву структурного насильства, яке вбудоване в соціальні структури російського суспільства і тримає його громадян у стані пасивності і страху перед владою (що Стефан Ессель вважає «найгіршою позицією» (2015)), стає фізичне насильство, яке виявляється в агресивній політиці. Звідси ж постає й інша форма насильства - культурне насильство, яке спрямоване на те, щоб подати інші форми насильства якщо не правомірними то принаймні виправданими, відволікти від фізичної агресії. Експансивна культурна політика, спрямована на пропагування російської культури, яку спостерігаємо впродовж останніх років в європейських країнах, і $є$ прикладом культурного насильства.

\section{3. До диференціації термінів «вербальна агресія» та «вербальне насильство»}

Виходячи із функцій агресивних мовленнєвих актів, ми розмежовуємо вербальну агресію від вербального насильства і виділяємо дві можливості їхнього вживання - спрямовану на насильство і ненасильницьке вживання. У першому випадку важливо виокремити вербальне насильство як окрему самостійну форму насильства і сенсибілізувати носіїв мови щодо мовленнєвих дій, які, згідно $з$ теорією мовленнєвих актів (Д. Серля та Д. Остіна) і теорією перформативності Юдит Батлер (Butler, 2006), можуть бути такими ж насильницькими діями як і фізична агресія.

Для дефініції вербальної агресії вирішальну роль відіграє ілокутивний аспект, звідси ми маємо справу із мовленнєвою дією або із мовленнєвим актом у вузькому значенні цього терміну. Для визначення вербального насильства недостатньо лише аналізу ілокутивного атку, адже вирішальним для насильства $є$ перлокутивний аспект (перлокутивний ефект). Мовне насильство може здійснюватися i без застосування агресивних мовленнєвих актів: поширення неправдивої інформації, вигадування безглуздих завдань. Мовленнєві дії можуть трактуватися як вербальне насильство також і з позиції третьої особи (слухача), проте сприйняття адресата є вирішальним - на такій позиції стоїть і сучасна філософія 
мови: «У будь якому разі вирішувати що є мовним насильством, повинні ті, на кого воно спрямоване. Цього не можна зробитина основі поширеного в теорії мовленнєвих актів аналізу, який опирається виключно на наміри мовця» (Liebsch, 2007:136). 3 огляду на диференціацію «вербальна агресія» - «вербальне насильство» відрізняється і роль адресата:

- у разі вербальної агресії наявність адресата $\epsilon$ факультативною - так, адресат відсутній в агресивних вигуках, які спрямовані на ситуацію; непряма вербальна агресія відбувається також за відсутності адресата;

- якщо мова йде про вербальне насильство, то наявність адресата $\epsilon$ обов' язковою.

Існує погляд, що про насильство можемо говорити лише в тому разі, коли йдеться про асиметричні стосунки (наприклад, насильство з боку керівника щодо підлеглого, вчителя щодо учня тощо). Беручи до уваги поширені випадки вербального мобінгу в колі колег чи учнівських групах, не можемо погодитися 3 такою позицією i не вважаємо асиметричність стосунків неодмінною умовою для визначення насильства.

На завершення хочемо торкнутися ще одного важливого аспекту, якому не відведено належної уваги ні в науковій літературі, ні в конкретних превентивних заходах щодо зниження вербального насильства: таким же важливим як сенсибілізація щодо інших є й десенсибілізація щодо себе самого. Оскільки в пейоративах домінує конотативний аспект, а предметне значення відходить на другий план, тому лайливі слова реферують не до зовнішнього світу, а до внутрішніх переживань мовця (пор. Wierzbicka, 1973:146), яка подає репрезентацію конотативного аспекту за допомогою модальної рамки «я почуваюся» (на відміну від сигніфікативного, який репрезентує модальна рамка «я хочу вам повідомити»). Учасники комунікації, передусім адресат, повинні усвідомлювати, що вербально-агресивні висловлювання характеризують не його, а мовця, адже вони $є$ виявом його темпераменту, емоцій, його проблем і страхів, його слабкості чи безпорадності. Цей аспект найкраще проілюструє цитата 3 роману Гарпер Лі «Вбити пересмішника»: «Скауте, чорнолюбець - одне зі слів, які нічого не означають, так само як і шмаркач. Це важко пояснити ... неотесані, ниці люди вживають його, коли їм здається, що хтось поважає негрів більше ніж їх. Так вони називають таких, як ми, коли їм хочеться грубо і вульгарно когось обізвати. /.../ доню, якщо тебе обз ивають якимось поганим словом, це не образа. Це просто показує, наскільки жалюгідна та людина, і не повинно тебе зачіпати. Не переймайся через місіс Дьюбоз, нехай вона лається. У неї дуже багато власних проблем» (2015:149).

\section{4. Висновки}

Вербальна агресія - це комплексний феномен, в основі якого лежать різні комунікативні інтенції, а намір образити, принизити адресата (насильницька інтенція) відіграє незначну роль - $11 \%$ в обидвох опитуваннях. Цим підтвердилася наша гіпотеза про те, що для вербальної агресії вирішальну роль відіграє не інтенція образи, а звільнення від негативних емоцій (катартична функція - 64 \% 
у першому опитуванні та $73 \%$ - у другому). При жартівливому вживанні агресивних мовленнєвих актів (25\% у першому та 16 - у другому) маємо справу із фіктивною вербальною агресією і їі продуктивними функціями.

Вживання агресивних мовленнєвих актів виконує ряд функцій, які ми трактуємо як продуктивні: катартична, втішальна, похвальна, театральна, корпоративна, підсилювальна.

Для вербальної агресії характерна функціональна полярність:

а) як заміна фізичної агресії і провокація до неї;

б) як насильство (з метою приниження, образи адресата) і як вияв близьких стосунків (лаудативне, пестливе вживання пейоративів, театральна, корпоративна, втішальна функція);

в) вербальна агресія як вияв влади (демонстрація власної соціальної позиції, яка дозволяє переступати через заборони вживання, ламати табу i чинити мовне насильство) і вербальна агресія у ситуаціях, коли інші засоби не допомагають і мовець лається із безсилля і розпачу.

- Виходячи з комунікативних інтенцій і функцій агресивних мовленнєвих актів, ми розмежовуємо вербальну агресію від вербального насильства і виділяємо дві можливості вживання агресивних мовленнєвих актів - спрямоване на насильство і ненасильне вживання.

- Проводячи лінію поділу між вербальною агресією і вербальним насильством, ми розглядаємо вербальну агресію не лише як замінник фізичного, але й вербального насильства.

- Наслідки структурного насильства «страх» $\mathrm{i}$ «пасивність» - причина і вербального, і фізичного насильства.

\section{Acknowledgements}

Дослідження й опитування проводилися в межах стажування в Інституті германістики Віденського університету за сприяння наукового фонду FWF (2006-2008 та 2012-2017).

\section{Література}

Aman, R. (1972). Psychologisch-sprachliche Einleitung in das Schimpfen. In: Bayrisch-Österreichisches Schimpfwörterbuch, (S. 153-188). R. Aman(Hg.). München: Süddeutscher Verlag.

Bach, G. R., Goldberg, H. (1981). Keine Angst vor Aggression. Die Kunst der Selbstbehauptung. FaM: Fischer.

Biffar, R. (1994). Verbale Aggressionsstrategien. Analyse, Systematik, Anwendung. Aachen: Shaker.

Burgen, S. (1998). Bloody hell, verdammt noch mal! Eine europäische Schimpfkunde. München: Dt. Taschenbuch.

Butler, J. (2006). Haß spricht. Zur Politik des Performativen. FaM: Suhrkamp.

Cherubim, D. (1991). Sprache und Aggression. Krieg im Alltag - Alltag und Krieg. Loccumer Protokolle, 58, 11-35.

Devkin, V. D. (1996). Der russische Tabuwortschatz, Leipzig: Langenscheidt Enzyklopädie.

Ehalt, Ch. (2015). Vorwort. In: Schmäh als ästhetische Strategie der Wiener Avantgarde, (S. 7-10). Suchy, I., Krejci, H. (Hg.).Weitra: Bibliothek der Provinz.

Ermen, I. (1996). Fluch - Abwehr - Beschimpfung. Pragmatik der formelhaften Aggression im Serbokroatischen. FaM u.a.: Peter Lang. 
Faust, M. (1970). Metaphorische Schimpfwörter. Indogermanische Forschungen, 74, 57-47.

Fiehler, R. (1990). Kommunikation und Emotion. Berlin u.a.: Walter de Gruyter.

Freud, S. (1994). Der Humor. In: S. Freud Studienausgabe Bd. IV, (S. 275-282). A. Mitscherlich, J. Strachey, A. Richards (Hg.). FaM: Fischer.

Gauger, H-M. (2012). Das Feuchte und das Schmutzige. Kleine Linguistik der vulgären Sprache. München: Beck.

Graber, H. G. (1931). Zur Psychoanalyse des Fluchens. Psychoanalytische Bewegung, 3, 57-68.

Havryliv, O. (2009). Verbale Aggression. Formen und Funktionen am Beispiel des Wienerischen. FaM, Wien u.a.: Peter Lang.

Herrmann, S. K., Krämer, S., Kuch, H. (Hg.). (2007). Verletzende Worte. Die Grammatik sprachlicher Missachtung. Bielefeld: Transcript.

Hess-Lüttich, E.W.B. (2008). HimmelHerrgottSakrament! Gopfridstutz! und Sacklzement! Vom Fluchen und Schimpfen - Malediktologische Beobachtungen. Kodikas/Code. An International Journal of Semiotics, 31(3-4), 327-337.

Holzinger, H. (1984). Beschimpfungen im heutigen Französisch. Pragmatische, syntaktische und semantische Aspekte. Ph.D. Dissertation: Universität Salzburg.

Kiener, F. (1983). Das Wort als Waffe. Zur Psychologie der verbalen Aggression. Göttingen: Vandenhoek \& Ruprecht.

Kotthoff, H., Jashari, S., Klingenberg, D. (2013). Komik (in) der Migrationsgesellschaft. Konstanz und München: UVK Verlagsgesellschaft.

Krämer, S. (Hg.) (2010). Gewalt in der Sprache. Rhetoriken verletzenden Sprechens. München: Wilhelm Fink.

Liebsch, B. (2007). Subtile Gewalt. Weilerswirt: Velbrück Wiss.

Lötscher, A. (1980). Lappi, Lööli, blööde Siech! Schimpfen und Fluchen im Schweizerdeutschen. Frauenfeld: Huber.

Mokienko, V., Walter, H. (1999). Lexikographische Probleme eines mehrsprachigen Schimpfwörterbuchs. Anzeiger für slawische Philologie, XXVI, 199-210.

Opelt, I. (1965). Die lateinischen Schimpfwörter und verwandte sprachliche Erscheinungen. Heidelberg: Winter.

Rehbock, H. (1987). Konfliktaustragung in Wort und Spiel. Analyse eines Stre itgesprächs von Grundschulkindern. In: Konflikte in Gesprächen, (S. 176- 238). G. Schank, J. Schwitalla (Hg.). Tübingen: Gunter Narr.

Schumann, H. B. (1990). Sprecherabsicht: Beschimpfung. Zeitschrift für Phonetik, Sprachwissenschaft und Kommunikationsforschung, 43, 259-281.

Schwarz-Friesel, M. (2013). Sprache und Emotion. Tübingen und Basel: Francke.

Searle, J. R. (1971). Sprechakte. Ein sprachphilosophischer Essay. FaM.: Suhrkamp.

Sornig, K. (1975). Beschimpfungen. Grazer Linguistische Studien, 1, 150- 170.

Ставицька Л. Українська мова без табу. Словник нецензурої лексики та ії відповідників. К: Критика, 2008.

Wierzbicka, A. (1973). Problems of expression: Their place in the semantic theory. In: Recherches sur les sestemes Signifiants. Symposium de Varsovie 1968, (S. 145-164). The Hague: Mouton.

Жельвис В. И. Поле брани: сквернословие как социальная проблема в языках и культурах мира. М: Ладомир, 1997.

\section{References (translated and transliterated)}

Aman, R. (1972). Psychologisch-sprachliche Einleitung in das Schimpfen. In: Bayrisch-Österreichisches Schimpfwörterbuch, (S. 153-188). R. Aman (Hg.). München: Süddeutscher Verlag.

Bach, G. R., Goldberg, H. (1981). Keine Angst vor Aggression. Die Kunst der Selbstbehauptung. FaM: Fischer.

Biffar, R. (1994). Verbale Aggressionsstrategien. Analyse, Systematik, Anwendung. Aachen: Shaker. 
Burgen, S. (1998). Bloody hell, verdammt noch mal! Eine europäische Schimpfkunde. München: Dt. Taschenbuch.

Butler, J. (2006). Haß spricht. Zur Politik des Performativen. FaM: Suhrkamp.

Cherubim, D. (1991). Sprache und Aggression. Krieg im Alltag - Alltag und Krieg. Loccumer Protokolle, 58, 11-35.

Devkin, V. D. (1996). Der russische Tabuwortschatz. Leipzig: Langenscheidt Enzyklopädie.

Ehalt, Ch. (2015). Vorwort. In: Schmäh als ästhetische Strategie der Wiener Avantgarde, (S. 710). Suchy, I., Krejci, H. (Hg.). Weitra: Bibliothek der Provinz.

Ermen, I. (1996). Fluch - Abwehr - Beschimpfung. Pragmatik der formelhaften Aggression im Serbokroatischen. FaM u.a.: Peter Lang.

Faust, M. (1970). Metaphorische Schimpfwörter. Indogermanische Forschungen, 74, 57-47.

Fiehler, R. (1990). Kommunikation und Emotion. Berlin u.a.: Walter de Gruyter.

Freud, S. (1994). Der Humor. In: S. Freud Studienausgabe Bd. IV, (S. 275-282). A. Mitscherlich, J. Strachey, A. Richards (Hg.). FaM: Fischer.

Gauger, H-M. (2012). Das Feuchte und das Schmutzige. Kleine Linguistik der vulgären Sprache. München: Beck.

Graber, H. G. (1931). Zur Psychoanalyse des Fluchens. Psychoanalytische Bewegung, 3, 57-68.

Havryliv, O. (2009). Verbale Aggression. Formen und Funktionen am Beispiel des Wienerischen. FaM, Wien u.a.: Peter Lang.

Herrmann, S. K., Krämer, S., Kuch, H. (Hg.). (2007). Verletzende Worte. Die Grammatik sprachlicher Missachtung. Bielefeld: Transcript.

Hess-Lüttich, E.W.B. (2008). HimmelHerrgottSakrament! Gopfridstutz! und Sacklzement! Vom Fluchen und Schimpfen - Malediktologische Beobachtungen. Kodikas/Code. An International Journal of Semiotics, 31(3-4), 327-337.

Holzinger, H. (1984). Beschimpfungen im heutigen Französisch. Pragmatische, syntaktische und semantische Aspekte. Ph.D. Dissertation: Universität Salzburg.

Kiener, F. (1983). Das Wort als Waffe. Zur Psychologie der verbalen Aggression. Göttingen: Vandenhoek \& Ruprecht.

Kotthoff, H., Jashari, S., Klingenberg, D. (2013). Komik (in) der Migrationsgesellschaft. Konstanz und München: UVK Verlagsgesellschaft.

Krämer, S. (Hg.) (2010). Gewalt in der Sprache. Rhetoriken verletzenden Sprechens. München: Wilhelm Fink.

Liebsch, B. (2007). Subtile Gewalt. Weilerswirt: Velbrück Wiss.

Lötscher, A. (1980). Lappi, Lööli, blööde Siech! Schimpfen und Fluchen im Schweizerdeutschen. Frauenfeld: Huber.

Mokienko, V., Walter, H. (1999). Lexikographische Probleme eines mehrsprachigen Schimpfwörterbuchs. Anzeiger für slawische Philologie, XXVI, 199-210.

Opelt, I. (1965). Die lateinischen Schimpfwörter und verwandte sprachliche Erscheinungen. Heidelberg: Winter.

Rehbock, H. (1987). Konfliktaustragung in Wort und Spiel. Analyse eines Streitgesprächs von Grundschulkindern. In: Konflikte in Gesprächen, (S. 176- 238). G. Schank, J. Schwitalla (Hg.). Tübingen: Gunter Narr.

Schumann, H. B. (1990). Sprecherabsicht: Beschimpfung. Zeitschrift für Phonetik, Sprachwissenschaft und Kommunikationsforschung, 43, 259-281.

Schwarz-Friesel, M. (2013). Sprache und Emotion. Tübingen und Basel: Francke.

Searle, J. R. (1971). Sprechakte. Ein sprachphilosophischer Essay. FaM.: Suhrkamp.

Sornig, K. (1975). Beschimpfungen. Grazer Linguistische Studien, 1, 150- 170.

Stavyc'ka, L. (2008). Ukraïns'ka mova bez tabu. Slovnyk necensurnoï leksyky ta ï̈ vidpovidnykiv [Ukrainian language without taboo. Dictionary of abusive vocabulary and its correspondence]. Kyiv: Klass yka.

Wierzbicka, A. (1973). Problems of expression: Their place in the semantic theory. In: Recherches sur les sestemes Signifiants. Symposium de Varsovie 1968, (S. 145-164). The Hague: Mouton. 
Zhelvis, V.I. (1997). Pole brani: skvernosloviye kak socialnaya problema v yasykax i kulturax mira [Field of Battle: Foul Language as a Social Problem in the Languages and Cultures of the World]. Moscow: Ladomir.

\section{Джерела}

Галкіна С. У Кремлі не збираються доходити до Києва і Львова. Високий замок, 19. 02. 25.02.15,6.

Ерофеев В. Русский апокалипсис. Retrieved from: Broyallib.ru/book/erofeev_viktor/ russkiy_apokalipsis html (12.02.2014).

Hessel, S. Empört euch! Retrieved from: http://jerome-segal.de/empoert_euch.pdf (27.02.2015).

Лагерлеф С. Чудесна мандрівка Нільса Гольгерсона 3 дикими гусьми / С. Лагерлеф. К: Веселка, 1991.

Лі Г. Вбити пересмішника / Г. Лі. К: Компан ія Осма, 2015.

Майже половина українців вживає ненормативну лексику. Retrieved from http://life.pravda.com.ua/society/2013/09/25/139569/(29.05.2013).

Путін хуйло. Retrieved from: https://uk.wikipedia.org/wiki/Путін____хуйло! (15.06.2016).

\section{Sources (translated and transliterated)}

Galkina, J. U Kremli ne zbyrayutsia doxodyty do Kyiva i Lvova [The Kreml is not going to go to Kyiv or Lviv]. Vysokyj zamok, 19. 02. - 25.02.15,6.

Yerofeyev, V. Russkij apokalipsis [The Russian Apocalypse]. Retrieved from: Broyallib.ru/book/ erofeev_viktor/russkiy_apokalipsis html (12.02.2014).

Lagerlöf, S. (1991). Chudesna mandrivka Nilsa Holhersona z dykymy hus'my [The Wonderful Adventures of Nils]. Kyiv: Veselka.

Lee, H. (2015). Vbyty Peresmishnyka [To Kill a Mockingbird]. Kyiv: Kompania Osma.

Mayzhe polovyna ukraïnciv vzhyvaye nenormatyvnu leksyku [Almost half of Ukrainians use abusive vocabulary]. Retrie ved from http:/life.pravda.com.ua/society/2013/09/25/139569/ (29.05.2013).

Putin Xuylo [Putin is Asshole]. Retrieved from: https://uk.wikipedia.org/wiki/Пугін___хуйло! (15.06.2016). 